\title{
Erratum to: Fertility rates among very young adolescent women: temporal and spatial trends in Brazil
}

Ana Luiza Vilela Borges ${ }^{*}$, Christiane Borges do Nascimento Chofakian ${ }^{1}$, Ana Paula Sayuri Sato ${ }^{2}$, Elizabeth Fujimori ${ }^{1}$, Luciane Simões Duarte ${ }^{1}$ and Murilo Novaes Gomes ${ }^{3}$

\section{Erratum}

After publication of the original article [1], it came to the authors' attention that a source of funding for the study was inadvertently omitted from the Acknowledgements section. The authors would like to add the following statement in the Acknowledgements section:

Publication of this article was funded by the São Paulo Research Foundation (FAPESP) (process 2016/03933-6).

\footnotetext{
Author details

'School of Nursing, University of São Paulo, Av. Dr. Enéas Carvalho de Aguiar 419, Cerqueira César, CEP 05403-000 São Paulo, SP, Brazil. ${ }^{2}$ Department of Epidemiology, Faculty of Public Health, University of São Paulo, São Paulo, Brazil. ${ }^{3} \mathrm{CDA}$-Agricultural Defense Coordination, São Paulo, Brazil.
}

Received: 18 July 2016 Accepted: 18 July 2016

Published online: 03 August 2016

\section{Reference}

1. Borges ALV, Chofakian CBN, Sayuri Sato AP, Fujimori E, Duarte LS, Gomes $\mathrm{MN}$. Fertility rates among very young adolescent women: temporal and spatial trends in Brazil. BMC Pregnancy Childbirth. 2016;16:57.

\footnotetext{
*Correspondence: alvilela@usp.br

'School of Nursing, University of São Paulo, Av. Dr. Enéas Carvalho de Aguiar 419, Cerqueira César, CEP 05403-000 São Paulo, SP, Brazil

Full list of author information is available at the end of the article
}

Submit your next manuscript to BioMed Central and we will help you at every step:

- We accept pre-submission inquiries

- Our selector tool helps you to find the most relevant journal

- We provide round the clock customer support

- Convenient online submission

- Thorough peer review

- Inclusion in PubMed and all major indexing services

- Maximum visibility for your research

Submit your manuscript at www.biomedcentral.com/submit 